\title{
Race and native speakers in ELT: parents' perspectives in Hong Kong
}

\author{
CHIT CHEUNG MATTHEW SUNG
}

\author{
Chinese parents in Hong Kong err in their perceptions of \\ racial background and the native speaker of English
}

\section{Introduction}

English is used as an important means of international and intercultural communication around the world more than ever. Because of its widespread use in the global context, non-native speakers of English around the world outnumber native speakers by far (Crystal, 1997). According to Kachru and Nelson (1996: 79), 'accepting even cautious estimates, there must be at least three nonnative users of English for every old-country native user'. A similar phenomenon is also observable in the English Language Teaching (ELT) profession, with the vast majority of teachers of English as a second and foreign language in the world being non-native speakers.

However, despite the vast number of non-native speaker teachers of English around the world, numerous cases of discrimination against nonnative English-speaking teachers have been reported, especially in relation to employment (e.g., Braine, 1999, 2010; Clark \& Paran, 2007), and native English-speaking teachers are still preferred over non-native English-speaking teachers when employment decisions are made. An apparent reason for the discrimination against non-native English teachers is that students prefer to be taught by native speakers (see Braine, 1999, 2010). For instance, Braine (1999) reported that at the master's degree level, while most ELT jobs are restricted to intensive English programs, few nonnative speakers (NNSs) have managed to break the unwritten rule 'No non-native speakers need apply'. Amin (1997) also documented how being non-white has negatively influenced the relations of some non-native teachers in Canada with their students, because the students equate only white people with native English speakers and believe that only native speakers know 'real' English.

Despite the recognition that non-native English teachers possess considerable strengths in teaching English in the literature (e.g., Benke \& Medgyes, 2005; Braine, 2010; Mahboob, 2004), native speakers are still preferred by some employers in China, as evidenced in the preferences and requirements specified in job advertisements for English language teachers (see below). What is more striking is that not only are 'native' English speakers required, but native speakers of a specific race are considered preferable. It is therefore worth examining how race is associated with the perception of

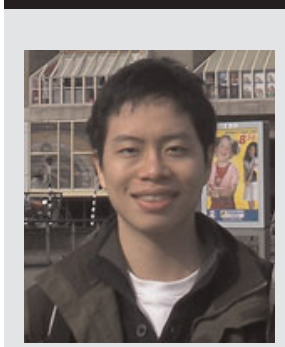

CHIT CHEUNG MATTHEW SUNG is a PhD candidate in the Department of Linguistics and English Language at Lancaster University, UK. He received a first class degree and a Master of Philosophy in English from the University of Hong Kong. He also holds an MA in Applied Linguistics. His recent publications include journal articles in Changing English and English Text Construction, and book reviews in World Englishes, TESOL Quarterly, and Discourse and Society. His research interests include global Englishes, sociolinguistics, language education, and language and gender.

Email: c.sung@lancaster.ac.uk. 
the notion of 'native speaker'. In this article, I shall report on my observation at a private language institute in Hong Kong, with specific reference to the parents' perceptions of who an ideal English teacher should be.

\section{Race and the native speaker}

The issue of race and its relationship to the notion of native speaker has not been given much attention until recently (see Curtis \& Romney, 2006; Kubota \& Lin, 2006; Shuck, 2006; Romney, 2010). Despite being often neglected in the field of ELT, race is closely related to what most people perceive as 'real' native speakers. In particular, whiteness is often closely associated with nativeness. Indeed, it is not difficult to find numerous online job advertisements which specifically require not only 'native speakers', but also 'native speakers' who are white. Here are some of the job advertisements posted by various institutions in China looking for 'white native speakers' to fill the positions of English teachers.

Good command of the English language. Aged 25-55 with good health condition. White Native Speaker or near native speaker preferred. Chinese knowledge helpful, but NOT required. Male and female applicable. Bachelor's degree or above in any discipline; Education majors and classroom experience preferred, but not required

We need a native speaker (Caucasian) to teach spoken English. 2 hour/class, 100 yuan/hour.

We are now in urgently need of White native

English Speaker. We offer the position both available in South and north part of China Like Xichang Sichuan, Guangyuan Sichuan, Yancheng Jiangsu, Huaian Jiangsu, Tancheng Shandong, Weishan Shandong, Chaohu Anhui, Qingjiang Hubei, Shangrao Jiangxi, Pingxiang Jiangxi, inner Mongolia, Luochuan Shanxi, Taizhou Jiangsu, Dafeng Jiangsu, Luocun Foshan.

A school in Suzhou need a English teacher. Requirements: 1. Native English speaker, white, 25-50 years old. 2. Can start to work anytime. 3. less than 20 lessons per week, overtime (if any): 100 Yuan per hour. Benefits: $1.6000 \mathrm{rmb}$ per month. 2. Housing free (available during all holidays). 3. A rent-free, fully furnished apartment.

English Teacher (preferably Caucasian). We are a professional recruitment agency which directly recruits native English teachers who has obtained a
Bachelor's Degree, for teaching positions. We have many positions available.

In the advertisements listed above, white native speakers of English are preferred for the position of English teacher. In other words, not only is 'nativeness' considered an important criterion, but race is also implicated in what makes an ideal English teacher in many Chinese employers' minds. While some research studies have investigated the students' and employers' perceptions about native and non-native English teachers (e.g., Mahboob, 2004; Cheung \& Braine, 2007; Lasagabaster \& Sierra, 2005), little is known about how different stakeholders think about the importance of race in their conceptions of an ideal English teacher. In particular, studies on parents' perceptions about native and non-native English teachers are almost non-existent. In what follows, I shall discuss what some of the Hong Kong parents perceive as an ideal English teacher and how race is brought to the fore in their preference for an ideal English teacher.

\section{Native speaker English teacher}

The concept of 'native speaker' is a particularly elusive and ambiguous notion. A generally agreed upon definition of a native speaker has taken the circumstances of acquisition as the major criterion for defining a native speaker; that is, a native speaker is someone who acquires a language in early childhood (Piller, 2001; Davies, 2003). Cook (1999) also sees 'the language learnt first' as a crucial element in defining what constitutes a native speaker. In the ELT profession, it is commonly believed that native speakers are ideal language teachers. For example, they are assumed to be superior in their linguistic competence as compared to non-native speakers, and are regarded as owners of proper, authentic English (see Widdowson, 1994). According to Braine (1999) and Medgyes (1994), native speakers are also believed to possess a superior command of fluent, idiomatically correct language forms, are more knowledgeable about the cultural connotations of a language, and are the arbiters of the acceptability of any instances of the language.

However, it is problematic to define who is a native speaker and who is not. According to Davies (2003), no consensus exists as to what is the proper definition of a native speaker. He rejects the idea that the "native speaker is uniquely and permanently different from a nonnative speaker' (p. 45), arguing that the notion of nativeness in 
language is a 'myth', and that the native speaker construct is more of an idealized construction. Brutt-Griffler and Samimy (2001) also suggest that 'nativeness' constitutes a socially constructed identity rather than a linguistic category. According to Kramsch (1997), the native speaker status is determined by 'acceptance by the group that created the distinction between native and nonnative speakers' (p. 363). In other words, whether speakers of English are considered as 'native' or 'nonnative' speaker depends upon various social parameters, such as the preconceived notions of what native speakers should look like or sound like (Brutt-Griffler \& Samimy, 2001).

Although race is not considered to be a criterion of a 'native speaker' in the literature, both race and nativeness are part and parcel of the 'idealized native speaker', or the most valued English teacher in most people's mind (see Romney, 2010). In what follows, based on my personal experiences, I shall recount some instances which will help us understand how some of the parents in Hong Kong see race as closely tied to the notion of an ideal English teacher.

\section{Race and ideal English teachers: Hong Kong parents' perspectives}

In early 2009, I worked at a private language institute in Hong Kong which offers English language courses to primary and secondary ESL students. One of the selling points of the institute is that most classes are taught by 'foreign teachers' (note that 'foreign teachers' are used, as opposed to 'native English speaker teachers'). Few classes are taught by local non-native English teachers. While I was working at the institute, I often overheard many parents talking to the clerk responsible for enrolment and registration about how much they wanted their children to be taught by 'foreign teachers', because they thought that their children would then speak English with a native accent.

An incident which I still vividly remember shows how a white foreign teacher was preferred by the parents, despite her lack of proficiency in English. In the institute, one of foreign teachers was from a south European country (exact location withheld for ethical reasons). I was quite surprised to find that she was hired because she was not a native speaker of English. I also expected that 'foreign teachers' meant 'native speaker teachers'. I was later told by the clerk that she did not hold any degrees, or any qualifications in TESOL or applied linguistics before teaching English. What is more striking is that her spoken English was not very advanced. The only qualification she had received was a pass in Cambridge First Certificate in English (CFE) showing that she was able to use everyday written and spoken English at an upper-intermediate level. This is not sufficient to qualify a person to teach English as a second language. I soon noticed her lack of proficiency when I had a conversation with her in English one day. Her strong European-language accent and lack of full grammatical proficiency in English was apparent to me in our conversations and in her speech to parents and colleagues. In the parents' mind, however, it seems that white foreign teachers are automatically native speakers of English and speak a variety of English which is superior to any other varieties. This explains why they never doubted that she was a native speaker of English, despite her apparent lack of fluency. More importantly, the parents did not seem to show any awareness that not all white 'foreign' teachers can speak English well enough to teach it.

Another related instance concerns the parents' distrust of native speaker teachers of colour. I recall a complaint made by a parent to the clerk in 2009 that her child was being taught by a teacher of Indian descent. The teacher, who was born and raised in the UK, was a native speaker of English, yet was perceived to be someone who speaks 'with an accent' because of her appearance. It is unlikely that the parent had spoken to the teacher before or had heard her speak any English, yet she was convinced that she spoke English 'with an accent'. Her judgment was solely based on the fact that the teacher was of Indian descent and the stereotype that people of Indian descent speak English 'with an accent'. The parent was worried that her child would not learn to speak with a 'native-speaker' accent. Consequently, she requested that her child be changed to a different class which was taught by a white British teacher.

A similar instance also shows doubts expressed by the parents concerning the authenticity of a native speaker of English who is of Chinese descent. At the language institute, a number of American-born Chinese (ABC), British-born Chinese (BBC) and Canadian-born Chinese (CBC) were employed as 'foreign teachers', alongside other white 'foreign teachers'. But a few parents were not convinced that people of Chinese descent could be native speakers of English. Indeed, they were considered less desirable than white 'foreign teachers'. For example, 
some parents were willing to pay extra money to put their children in a class taught by white foreign teachers, rather than by the $\mathrm{ABC}$ teachers. An embarrassing instance was recounted by an $\mathrm{ABC}$ teacher who is a native speaker of English and speaks English with no noticeable non-native accent. A parent requested to interview him personally before she allowed her child to join his English class, because she wanted to make sure that he is a 'real' native speaker and does not speak 'with an accent'. In addition, the parent was concerned about whether the $\mathrm{ABC}$ teacher spoke any Chinese. The clerk spent a long time trying to convince the parent that the $\mathrm{ABC}$ teacher was as good as other white foreign teachers. When the parent found out from the clerk that he did not speak any Chinese, she was relieved and started to believe that he could well be a 'real' native speaker. Yet, the parent still took a few weeks to consider the matter further before she enrolled her child with the $\mathrm{ABC}$ teacher.

What these incidents show is that native speakers are still believed to be ideal English teachers and that the notion of native speaker is perceived to be closely tied to race. In particular, the parents seem to equate 'whiteness' with 'nativeness', and are not generally aware of other possibilities. Their attitudes coincide with the perceived ownership of English by the inner circle and its speakers, which may account for the preference for 'white native speakers' among parents to be English language teachers. In other words, teachers with certain language backgrounds and racial backgrounds are still perceived to have a kind of value, and the embodiment of this value can be referred to as 'the idealized native speakers' (Romney, 2010).

Although bilingualism is the trend in most parts of the world, being bilingual seems to be perceived to be at odds with the native speaker status for non-white native speakers. This explains why some parents are concerned about whether the $\mathrm{ABC}$ teacher speaks Chinese or not.

\section{Conclusion}

The 'native speaker fallacy' is still evident in some parents' minds. For example, some parents believed that native speakers are superior to nonnative speakers because native speakers speak English with a 'standard' accent. It is therefore important to raise awareness among parents about the 'native speaker fallacy' (Phillipson, 1994), or the belief that native teachers are ideal language teachers. It is also essential to educate parents about the sociolinguistic reality surrounding the English language, especially in relation to the fact that English is used as a global language and that there are different varieties of English around the world. It is hoped that with more knowledge about the sociolinguistic reality of the English language, parents can develop a more tolerant attitude towards the diversity which exists among English teachers of different races, nationalities and mother tongues, and can give due recognition to the contributions that different kinds of English teachers make to the ELT profession, without showing biases towards specific types of English teachers.

\section{References}

Amin, N. 1997. 'Race and the identity of the nonnative ESL teacher.' TESOL Quarterly, 31(3), 580-3.

Benke, E. \& Medgyes, P. 2005. 'Differences in teaching behavior between native and non-native speaker teachers: As seen by the learners.' In E. Llurda (ed.), Non-native Language Teachers: Perceptions, Challenges and Contributions to the Profession. New York: Springer, pp. 195-215.

Braine, G. 1999. Introduction. In G. Braine, Non-native Educators in English Language Teaching. Mahwah, NJ: Erlbaum, pp. xiii-xx.

-. 2010. Nonnative Speaker English Teachers: Research, Pedagogy and Professional Growth. London: Routledge.

Brutt-Griffler, J. \& Samimy, K. K. 2001. 'Transcending the nativeness paradigm.' World Englishes, 20, 99-106.

Cheung, Y. L. \& Braine, G. 2007. 'The attitudes of university students towards nonnative speaker English teachers in Hong Kong.' RELC Journal, 38(3), 257-77.

Clark, E. L. \& Paran, A. 2007. 'The employability of non-native-speaker teachers of EFL: A UK survey.' System, 35(4), 407-30.

Cook, V. 1999. 'Going beyond the native speaker in language teaching.' TESOL Quarterly, 33(2), 185-209.

Crystal, D. 1997. English as a Global Language. Cambridge: Cambridge University Press.

Curtis, A. \& Romney, M. (eds). 2006. Color, Race and English Language Teaching: Shades of Meaning. Mahwah, NJ: Lawrence Erlbaum.

Davies, A. 2003. The Native Speaker in Applied Linguistics (2nd edn). Edinburgh: Edinburgh University Press.

Kachru, B. \& Nelson, C. 1996. 'World Englishes.' In S. Mackay \& N. Hornberger (eds), Sociolinguistics and Language Teaching. Cambridge: Cambridge University Press, pp. 71-102.

Kramsch, C. 1997. 'The privilege of the nonnative speaker.' PMLA, 112(3), 359-69.

Kubota, R. \& Lin, A. (eds). 2006. 'Race and TESOL.' TESOL Quarterly, 40(3), 471-93.

Lasagabaster, D. \& Sierra, J. M. 2005. 'What do students thing about the pros and cons of having a native speaker teacher?' In E. Llurda (ed.), Non-native Language Teachers: Perceptions, Challenges and Contributions to the Profession. New York: Springer, pp. 217-41. 
Mahboob, A. 2004. 'Native or nonnative: What do students enrolled in an intensive English program think?' In L. Kamhi-Stein (ed.), Learning and Teaching from Experience: Perspectives on Nonnative English-speaking Professionals. Michigan: Michigan University Press, pp. 121-47.

Medgyes, P. 1994. The Non-native Teacher. Hong Kong: Macmillan.

Phillipson, R. 1992. Linguistic Imperialism. Oxford: Oxford University Press.
Piller, I. 2001. 'Who, if anyone is a native speaker?' Anglistik: Mitteilungen des Verbandes Deutscher Anglisten, 12(2), 109-121.

Romney, M. 2010. 'The colour of English.' In A. Mahboob (ed.), The NNEST Lens. Newcastle upon Tyne: Cambridge Scholars, pp. 18-34.

Shuck, G. 2006. 'Racializing the nonnative English speaker.' Journal of Language, Identity and Education, 5(4), 259-76.

Widdowson, H. G. 1994. 'The ownership of English.' TESOL Quarterly, 28, 377-89.

\section{CAMBRIDGE ل}

\section{Journal of Linguistics}

\section{Editors \\ Nigel Fabb, University of Strathclyde, UK \\ Caroline Heycock, University of Edinburgh, UK \\ Robert D. Borsley, University of Essex, UK}

Journal of Linguistics has as its goal to publish articles that make a clear contribution to current debate in all branches of theoretical linguistics. The journal also provides an excellent survey of recent linguistics publications, with around thirty book reviews in each volume and regular review articles on major works marking important theoretical advances.

'The Journal of Linguistics is one of the top journals for theoretical linguistics. It's chock full of new ideas and wonderfully free of theoretical orthodoxy.' Ivan Sag, Stanford University

\section{Price information}

\section{is available at: $\mathbf{h t t p}: / /$ journals.cambridge.org/lin}

\section{Free email alerts}

Keep up-to-date with new material - sign up at http://journals.cambridge.org/alerts

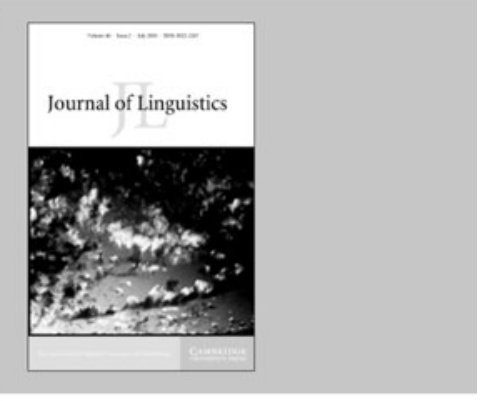

Journal of Linguistics is available online at: http://journals.cambridge.org/lin

To subscribe contact Customer Services

\section{in Cambridge:}

Phone $+44(0) 1223326070$

$\mathrm{Fax}+44(0) 1223325150$

Email journals@cambridge.org

\section{in New York:}

Phone +1 (845) 3537500

Fax +1 (845) 3534141

Email

subscriptions_newyork@cambridge.org 